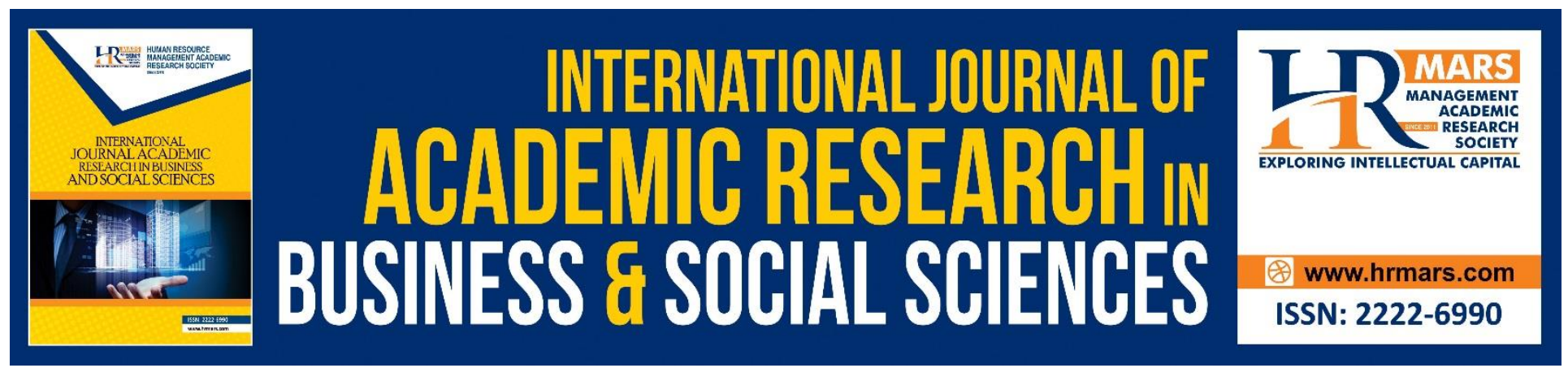

\title{
Evaluating Organizational Project Management Performance: Empirical Evidence from public Universities of Khyber Pakhtunkhwa, Pakistan
}

\author{
Salman Khan, Najamul Saqib Memon, Awais Ahmad
}

To Link this Article: http://dx.doi.org/10.6007/IJARBSS/v9-i3/5735

DOI: $\quad 10.6007 /$ IJARBSS/v9-i3/5735

Received: 09 Feb 2019, Revised: 27 Feb 2019, Accepted: 16 March 2019

Published Online: 23 March 2019

In-Text Citation: (Khan, Memon, \& Ahmad, 2019)

To Cite this Article: Khan, S., Memon, N. S., \& Ahmad, A. (2019). Evaluating Organizational Project Management Performance: Empirical Evidence from public Universities of Khyber Pakhtunkhwa, Pakistan. International Journal of Academic Research in Business and Social Sciences, 9(3), 676-690.

Copyright: (C) 2019 The Author(s)

Published by Human Resource Management Academic Research Society (www.hrmars.com)

This article is published under the Creative Commons Attribution (CC BY 4.0) license. Anyone may reproduce, distribute, translate and create derivative works of this article (for both commercial and non-commercial purposes), subject to full attribution to the original publication and authors. The full terms of this license may be seen

at: http://creativecommons.org/licences/by/4.0/legalcode

Vol. 9, No. 3, 2019, Pg. 676 - 690

http://hrmars.com/index.php/pages/detail/IJARBSS

JOURNAL HOMEPAGE

Full Terms \& Conditions of access and use can be found at http://hrmars.com/index.php/pages/detail/publication-ethics 


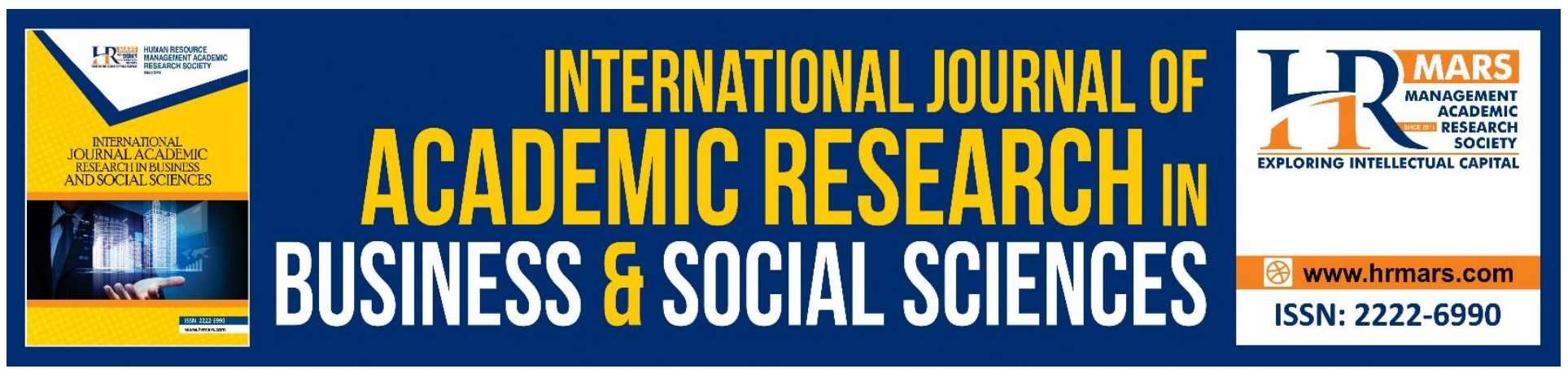

\title{
Evaluating Organizational Project Management Performance: Empirical Evidence from public Universities of Khyber Pakhtunkhwa, Pakistan
}

\author{
Salman Khan \\ Public Policy and Good Governance, Political Science Department - University of Passau, Germany \\ Email:khan04@gw.uni-passau.de \\ Najamul Saqib Memon \\ Public Policy and Good Governance, Political Science Department - University of Passau, Germany
}

Email: saqib01@gw.uni-passau.de

Awais Ahmad

Public Policy and Good Governance, Political Science Department - University of Passau, Germany

Email: ahmad09@gw.uni-passau.de

\begin{abstract}
The paper explores how the project culture and organizational leadership play an important role in organizational project management performance. To what extent organizational project management maturity is used, close-ended questionnaires have been collected from the 85 respondents within the planning and development department of public universities of Khyber Pakhtunkhwa province, Pakistan. The regression model was used and the result shows that project culture and organizational leadership have a positive relationship with organizational project management performance in public universities. It is concluded that the study has a prospective use as framework to assess the project management performance, by conducting empirical study and checking the impact. The study also contributes to establish clear reference points based on leadership qualities and mature organizational project management to allow organizations to determine roadmap to higher maturity level.
\end{abstract}

Keywords: Project management performance, organizational leadership, project culture, public universities of Khyber Pakhtunkhwa 
INTERNATIONAL JOURNAL OF ACADEMIC RESEARCH IN BUSINESS AND SOCIAL SCIENCES

Vol. 9, No. 3, March, 2019, E-ISSN: 2222-6990 @ 2019 HRMARS

\section{Introduction}

Despite the important role of education in the development of social of emerging nations, in addition, the serious part it shows in growth, the presentation of the education leftovers usually little. Few plans in emerging states happenstance substantial schedule and budget invades, flop to understand their envisioned profit or even totally ended and uncontrolled earlier or after their conclusion (Dawn News, 26 April 2010). The uncontrollable factors lead us to the project management.

The value of project management is recognized in almost all kind of organizations and integrated into the core activities of the organizations. The percentage of project management in to organization is growing day-by-day (Bredillet, Thomas, \& Musila, 2012). Today, project management important topic in many fields. Much literature is available, but it is not enough because everyone shows different aspects of the field but different in opinions do not decrease the importance of the project management. Moreover, the world has shown tremendous progress in the field. It involves managing a small project such as arranging a small event to more complex projects such as sending aircraft in space. All projects are based on some specific objectives and to meet those objectives, organizational project management must give performance satisfactory. Therefore, it is important to investigate all constraints which the organization encounters during the projects.

It is very difficult to choose the framework for measuring organizational management performance. Numerous organizations from the social, corporate and public sectors are claiming that "we manage project very effectively and our performance is outstanding".

Regardless of this claim, many organizations do not pay attention to the project management and invest in other part of the organizations. However, the project management is still a key area in the organizations (Oliveira Moraes \& Barbin Laurindo, 2013). The ignorance of many factors in the future, paying little attention to stakeholder management, and only emphasizing on project costs, scope, resources, time and specification of the project leave a lot of rooms for not meeting project objectives within given constraints but this is not limit and there are still many areas need to be cover during the project life cycle. In fact, the processes of project management are also known for tailoring. It is essential to for the organizations to come up with good project management performance assessment tools in order to achieve "best of the best". Project Management Institute presented the tool for investigating organizational project management performance, known as Organizational Project Management Maturity Model (OPM3). OPM3 can be describe as "the processes measured by the ability of an organization to successfully initiate, plan, execute, and monitor and control individual projects" but the project management maturity model is limited to individual projects and it does not highlight the processes of program, portfolio management. The only difference is, it focusses only on project management maturity and aiming "doing projects right". To some extent, project culture and organizational leadership are ignored in many of the models. Therefore, it is essential to investigate organizational project management maturity based on the project culture and leadership.

Project culture assumed to be a prominent part of the project management settings (Zuo, Zillante, Zhao, \& Xia, 2014). Culture is a set of values, norms, attitudes, behaviors and most often it is a primary way to differentiate one group from another (Mukherjee, Lahiri, Mukherjee, \& Billing, 2012). Therefore, it has a positive and unified impact on project success (Zuo et al., 2014). On the other hand, organizational leadership is also paramount to the success of project management. It is a field of study in which goals are setting, creating and communicating vision, managing stuff, good 
behavioral approach and being a leader. It is crucial to the organizational management but it is also important in the context of organizational project management performance.

In Pakistan, many organizations are claiming that the projects are managed effectively and the performance is outstanding. Despite this, many organizations ignore to devote much time to organizational project management. They are living in present and they forget about future. They used old practices and do not pay attention to the competition in future. Moreover, less importance is given to the organizational project management in public sector organization. Lack of proper planning, lack of administration, and leadership skills are the key factors for failure. In order to cover up these failures, organizations need good project management performance in order to make an organization best out of the best.

The purpose of the study is to evaluate the organizational project management performance in public universities of KPK, Pakistan, which ensures that the universities have challenges with the project culture and organizational leadership. Furthermore, the study aimed to serve as a groundwork for future studies by spotting critical factors in the development of organizational project management performance.

The first section highlights the conceptualization and literature on project management performance, project culture and organizational leadership. The second section is the hypothesis and then followed by the research methodology. The third section is the result analysis and in the last discussion, conclusion, and limitations.

\section{Research objectives}

- To Investigate organizational project management performance in the public universities of Khyber Pakhtunkhwa.

- Measure to what extend the procedures and best practices of project management are functional by planning and development in managing projects.

- To examine the maturity of project management practices in research \& development of public universities of Khyber Pakhtunkhwa.

\section{Literature Review}

\section{Organizational Project Management}

Few authors suggested and have well-defined project and project management and emphasizing its different features with different concepts. According to one study "project a temporary endeavor (that has a definite starting point and finish time) assumed subsequent exact cycle of initiation, definition, planning, execution, controlling and close to produce a unique product, service, or result through original group and management of human, material and monetary resources" (Muriithi \& Crawford, 2003; Stanleigh, 2008). The definition of a project is further explained as "project is a temporary endeavor undertaken to create unique product service or result" (PMI, 2014). The project is finished with its objectives are meet, when the objectives are not meet, when the project stakeholders do not take much interest in the project objectives and conclude to terminate the project at any given phase of the project. In addition to the explanation, temporary does not mean the project is short in duration but the achievement of specific project objectives within a given time 
frame. Furthermost projects are started to generate a long-lasting outcome. Each project produces a distinctive product, service, or result. (PMBOK $5^{\text {th }}$, PMI, 2014).

The purpose of project management contains essential the obligation of effort, creating the degree of effort, assigning the resources obligatory, preparation the implementation of the effort, observing the development of the activities in the project and regulating nonconformities on or after the plan. (Bredillet et al., 2012). Project management can be defined as "a broad determination management tool that can carry projects to positive completion and to the fulfillment and satisfaction of the project stakeholders, agreed on the old-style constraints, distinct scope, anticipated quality, budgeted cost, and a timetable limit (Abbas, 2011; Bergman \& Gunnarson, 2014). Project management is an application to any association by the main objectives of scope, quality, schedule, and cost" (HUTSON, 1997). Furthermore, the main goal of project management is to meet stakeholder requirements within constraints.

Project management likenesses with the public sectors in the position of the project management process, tools and techniques, methods, and project management life cycle have definite matchless trails. Previous research contended that public organizations have no likeness with the private sector organizations irrespective application of project management (Stankosky \& Anantatmula, 2010). While some researchers onward have totally agreed upon that there are some similarities of public and private sector organization project management. Project management framework has better methodologies to manage the public organization in a different way. Nevertheless, these have not thoroughly verified in actual circumstances. (Abbas, 2011) proposed an objective-focused on and information grounded project management. The enterprise architecture for handling "techno change" projects, (Yang, Read, \& Miller, 2009) emphases on handling info movements in the public sector, while (Stuckenbruck \& Zomorrodian, 1987) suggest adjusting private project management to the public sector.

In widespread study completed in the public sector on the projects have shown that there are approximately 35 percent project failure in the world. 50 percent are partial failures and 15 percent are successful, which is the very low ratio in the world. Correspondingly a (World Bank study, 2005) assessments how showed that the application of public sector in under developing counties like Pakistan are a total failure because of improperly planning and the low application of project management. The issue to be consider the most important in public sector is the poor projects design and improper planning for the projects. It is consequently authoritative that suitable methods should be addressed and selected for the proper application of project management in the public organizations. However, to have successful projects in public organizations, an exclusive methodology and framework should be proper to apply on the public organization, keeping in mind that each county has a different business, culture, style, and frameworks (S. Abbasi \& Hollman, 2000; Arnaboldi \& Lapsley, 2004). There are certain mutual and main issues which need meaningfully disturb how projects are considered, planned, executed and controlled.

\section{Organizational Leadership}

The four comprehensive styles of the leadership that is, "the trait approach, the behavior approach, the contingency approach and the transformational and charismatic approach" (Kirkpatrick \& Locke, 1991; Kotter, 1990) but have given very limit importance to the style and leadership in project 
management. Few of the exact mechanisms of the tactics do suggest a character of leaders in project management but drop tiny of investigative methodically. The trait style identifies business information (an element of information management) as an important excellence of actual leaders (Kirkpatrick \& Locke, 1991). "The behavioral and contingency styles to the revision of leadership propose that information search and ahead and information use" (FLEISHMAN \& MUMFORD, 1991) are essential proportions of leader performance that have an influence of presentation. The performance of the leaders in enabling the being and obtainability of compulsory data and knowledge over and done with such methods as data management can have an important influence on organizational project management success. The charismatic approach suggests that data attainment and investigation is significant for the expansion of apparition in organizations (Kotter, 1990).

Irrespective of the growth and theories of leadership, successful project management has been considered the submission of tools and techniques of project manager's leadership style (PMI, 2014). Suggested by the first studies about the character and style of project manager into justification (Müller \& Turner, 2007; Rodney Turner, Müller, \& Dulewicz, 2009) where they are categories as megastars, or thick-skinned pragmatists, newcomers, uncreative decision makers, imaginative experts, and recognized the features of the projects that match with these different nature types. Newly, the project management derived to acknowledge that both the project management actions (Bergman \& Gunnarson, 2014) and the project manager's management capability should be reserved into account when passing on a project manager to a project (Müller \& Turner, 2007; Rodney Turner et al., 2009). However, it was presented by (Oliveira Moraes \& Barbin Laurindo, 2013) the overall position of demonstrative capabilities for successful projects accomplishment. Muller \& Turner (2007) have recognized the leadership scopes and styles of the ability which associated with the accomplishment of different kind of projects into different leadership styles through different project management types.

Situational leadership capabilities associate with project success in explicit conditions, such as static price agreements, or high difficulty in projects. The facts of these are additionally labeled in (Müller \& Turner, 2007). Auxiliary capabilities do not straightly correlate with project success but are quantities dimensions of the capability school constructs.

\section{Project Culture}

The 1980s saw an expression of management literature on the topic of culture, with the bestselling achievement of Peters and Waterman's "In Search of Excellence" the degree to which the type affected the emotions of the administration public. They focused on what influence be named the "behavioral side" of administration and organization. They have claimed that the variance between successful and non-successful organizations breaks with the standards and philosophies that motivate their inside organizations. Project culture is the word which has originate to include that customary behavioral variable that have pinched so considerable consideration. "culture" denotes the fundamental principles, morals, and philosophies that assist as the basis aimed at an organization's management scheme in addition to the established of management performs beside behaviors that together establish also strengthen those elementary philosophies (Denison, Janovics, Young, Hee, \& Cho, 2006). 
Project management is abundant debated nowadays (Locke, 2005) along with a study on project culture modification in diverse associations by means of it can importantly recover the part of workers by varying the organizational culture of a foundation (Istrate \& Marian, 2012). Maximum specialists admit that the instruments of organizational culture and project culture do not all have a similar level of conception and consistency (Wanna, 2007). Though, most researchers reflect the following components of organizational culture and project culture: signs, morals, ceremonies, and rules of conduct.

The idea of signs is used to describe organizational marvels and their appearances at diverse stages. Frequently signs are used in commerce with further cultures to rapid some comparisons or changes. A culture can be understood as a scheme of signs that are intended to uphold instruction and make it signify somewhat dissimilar or somewhat in excess of the sign itself, whether it is a substantial component or not. A third component mentions to the supposition that signs or the symbolic realism have their own judgment.

\section{The relationship between Project success and Project culture and leadership}

(Abbasi \& Al-Mharmah, 2000)study explore the project management techniques and tools charity by the civic segment in one of the developing countries by taking planning, scheduling and controlling into consideration. This theory was further elaborated which conducted to examine the influence of standardized project management on the development of projects success, (Milosevic \& Patanakul, 2005) where some needy variables are taken, the amount of projects accomplishment which are multi-element theory combining four principles and the degree to which the project proficient their cost, time and quality, and customer fulfillment goals and in response to standardized project management process, organization, metrics, information management systems, tools, project culture, and management. The importance and usage of maturity models in a different organization. More ever, the project management maturity model is classically charity not proactively (Backlund, Chronéer, \& Sundqvist, 2014). It is also presented to measure the connection between project management assets and competence (Mathur, Jugdev, \& Shing Fung, 2007).

Parchami and Matin (2014), stated that the organizational framework variables which had remained supposed to consume conclusive influence on project management workplaces features. It compares and classifies PMO's features beginning numerous reference (Parchami Jalal \& Matin Koosha, 2015).

\section{Model}

The goal of the study is to investigate the relationship between organizational project management performance and project culture and organizational leadership. 


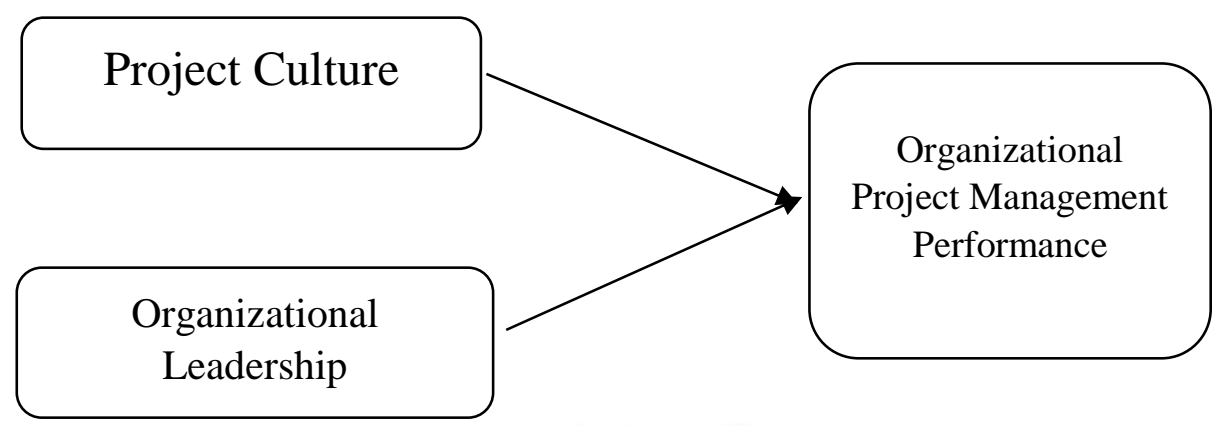

\section{$\underline{\text { Scientific Design }}$}

\section{$y=x_{1} a+x_{2} b+e i$}

\section{Hypothesis}

H1: Project culture has organizational project management performance.

a positive relationship with

$\mathrm{H}$ 2: Organizational leadership has a positive relationship with organizational project management performance.

\section{Methodology}

\section{Sample Size}

Respondents were selected from 18 public universities of KPK (Table 1). Few of them are well matured while some of them are newly born. 85 respondents were selected in the planning and development department and only 57 responded to the questionnaires (Table 2). The questionnaire was first used mailing assessment, but insufficient replies recorded. Consequently, the data gathering would be insufficient for analysis. In the next phase, the printed questionnaires were shared with them and they were observed during the process.

\section{Table 1:}

\begin{tabular}{lr}
\hline $\mathbf{1}$ & Abdul Wali Khan University, Mardan \\
\hline $\mathbf{2}$ & Bacha Khan University, Charsadda \\
\hline $\mathbf{3}$ & Frontier Women University, Peshawar \\
\hline $\mathbf{4}$ & Gomal University, D.I. Khan \\
\hline $\mathbf{5}$ & Hazara University, Dodhial Mansehra \\
\hline $\mathbf{6}$ & Islamia College University, Peshawar \\
\hline $\mathbf{7}$ & Khyber Pakhtunkhwa Agriculture University, Peshawar \\
\hline $\mathbf{8}$ & Khushal Khan Khattak University, Karak \\
\hline $\mathbf{9}$ & Kohat University of science and technology, Kohat \\
\hline 10 & Shaheed Benazir Bhutto University, Sheringal, Dir \\
\hline 11 & University of Malakand, Chakdara, Dir, Malakand \\
\hline $\mathbf{1 2}$ & University of Peshawar \\
\hline $\mathbf{1 3}$ & University of FATA, Kohat \\
\hline $\mathbf{1 4}$ & University of Science and Technology, Bannu \\
\hline 15 & University of Swat, Swat \\
\hline
\end{tabular}


INTERNATIONAL JOURNAL OF ACADEMIC RESEARCH IN BUSINESS AND SOCIAL SCIENCES

Vol. 9, No. 3, March, 2019, E-ISSN: 222 2-6990 @ 2019 HRMARS

\begin{tabular}{lr}
\hline 16 & University of Haripur, Haripur \\
\hline 17 & University of Sawabi, Swabi \\
\hline 18 & Women University, Hayatabad \\
\hline
\end{tabular}

Table2: University

\begin{tabular}{|c|c|c|c|c|c|}
\hline & & Frequency & Percent & Valid Percent & $\begin{array}{l}\text { Cumulative } \\
\text { Percent }\end{array}$ \\
\hline Valid & Public & 57 & 100.0 & 100.0 & 100.0 \\
\hline
\end{tabular}

\section{Data Collection and Treatment}

Initially, the questionnaire was shared with 150 members of planning and development department of which 14 were directors ( 3 to 15 years of experience) and 14 were assistant directors ( 1 to 9 years of experience). 10 respondents have given back the questionnaires. Of these 8 which given back the survey; a reply from 15 was disallowed as the replies were not comprehensive or suitably replied. From now only reply from the 85 staff members were recycled in carrying out the maturity investigation. After the data has been collected, a feel for the data got to eliminate the incomplete questionnaires and entered in SPSS. Means of all the scales were analyzed by computing them and Regression test was applied.

\section{Analysis}

In the first step, the feel for data got that is pay for absent values. In the second step, the normality of the data has been observed and in the third step, the Regression was used. In the fourth step, the goodness of data was checked which stood completely by inspection Cronbach alpha morals of all these variables.

\section{Respondent Details}

The respondent job title was categorized into planning and development director, assistant, project manager, office assistant, and others. A total of 57 respondents' response to the questionnaires. The study sample was dominated by respondents with the director, showed 5.3 percent of the total study sample while an assistant, showed 7.0 percent of the total. Most importantly others respond the highest with a frequency of 28 and a percentage of 49.1. It has been concluded that others (staff of the department) respond more and highest out of the total.

Table4: Job title

\begin{tabular}{llllll}
\hline & & Frequency & Percent & Valid Percent & $\begin{array}{l}\text { Cumulative } \\
\text { Percent }\end{array}$ \\
\hline Valid & Director & 3 & 5.3 & 5.3 & 5.3 \\
& Assistant & 4 & 7.0 & 7.0 & 12.3 \\
& Project Manager & 6 & 10.5 & 10.5 & 22.8 \\
& Office Assistant & 16 & 28.1 & 28.1 & 50.9 \\
& Others & 28 & 49.1 & 49.1 & 100.0 \\
& Total & 57 & 100.0 & 100.0 & \\
\hline
\end{tabular}


INTERNATIONAL JOURNAL OF ACADEMIC RESEARCH IN BUSINESS AND SOCIAL SCIENCES

Vol. 9, No. 3, March, 2019, E-ISSN: 222 2-6990 ¿ 2019 HRMARS

\section{Reliability}

There must be steadiness in the replies since discrepancy of replies interrupts the reliability of collected data. Reliability mentions to the methodical or reliable percentage of notches. If the data is not consistent then the extra investigation can central to mistaken deductions. Permissible to check the reliability of scales Cronbach's Alpha test stayed used.

Table 7: Reliability Statistics

\begin{tabular}{ll}
\hline Cronbach's Alpha & $\mathrm{N}$ of Items \\
.969 & 43 \\
\hline
\end{tabular}

Table 8: Least Square Method

\begin{tabular}{|c|c|c|c|c|}
\hline $\begin{array}{l}\text { Dependent Varia } \\
\text { Management Perfo }\end{array}$ & $\begin{array}{l}\text { Organ } \\
\text { mance }\end{array}$ & ational $\mathrm{Pr}$ & & \\
\hline Method: Least Squ & & & & \\
\hline Date: 05/01/15 Ti & ne: $15: 10$ & & & \\
\hline Sample: 186 & & & & \\
\hline Comprised observa & ions: 86 afte & vard adjustr & & \\
\hline Variable & Coefficient & Std. Error & t-Statistic & Prob. \\
\hline PNDT & -0.497328 & 0.119621 & -4.157518 & 0.0001 \\
\hline TRG & 1.028200 & 0.245515 & 4.187938 & 0.0001 \\
\hline AREXP & 1.471836 & 0.306483 & 4.802348 & 0.0000 \\
\hline ASSEXP & 0.309764 & 0.273337 & 1.133270 & 0.0085 \\
\hline DEXP & 0.517369 & 0.144416 & 3.582487 & 0.0006 \\
\hline C & -2.670001 & 0.445609 & -5.991808 & 0.0000 \\
\hline R-squared & 0.946819 & Mean d & ent var & 8.848837 \\
\hline $\begin{array}{l}\text { Adjusted } \\
\text { squared }\end{array}$ & 0.943496 & S.D. dep & t var & 3.891219 \\
\hline S.E. of regression & 0.924969 & Akaike i & iterion & 2.749101 \\
\hline Sum squared resid & 68.44540 & Schwarz & ion & 2.920335 \\
\hline Log-likelihood & -112.2113 & Hannan & n criteria. & 2.818015 \\
\hline F-statistic & 284.8611 & Durbin- & in stat & 0.449127 \\
\hline Prob(F-statistic) & 0.000000 & & & \\
\hline
\end{tabular}

\section{Planning and Development Team}

The sign of the planning and development team is negative and highly significant i.e. significant at 1 percent level which means that there is a negative connection between planning and development team and organizational project management performance. Planning and development team significantly effects over depend on organizational project management performance. 
The negative sign with the coefficient of the planning and development team displays that there is an adverse relationship with the number of planning and development team and organizational project management performance. Planning and development are overpopulated so it effects on organizational project management performance negatively.

\section{Other Variables}

The sign of training variable is positive and highly significant that is at 1 percent level significant. There is a positive relationship between the training of planning and development staff and organizational project management performance. It means the training enhances the organizational project management performance because training courses enhance the skills and enhance efficiency. So, the public universities must provide more and more training to planning and development team. The coefficient of assistant experience has a positive sign which is highly significant (1 percent level of significance) and have a positive relationship with organizational project management performance. The more experience the assistant, the better will be organizational project management performance. The coefficient of director's experience is positive and highly significant and a positive relationship with organizational project management performance.

The coefficient of project initiatives is positive and highly significant and positive relationship with organizational project management performance. The more project initiated by public universities, the better will be organizational performance and hence better the overall organizational performance.

Table 9: Least Square Method

\begin{tabular}{|c|c|c|c|c|}
\hline \multicolumn{5}{|c|}{$\begin{array}{l}\text { Dependent Variable: Organizational Project Management } \\
\text { Performance }\end{array}$} \\
\hline \multicolumn{5}{|c|}{ Method: Least Squares } \\
\hline \multicolumn{5}{|c|}{ Date: 05/01/15 Time: 15:15 } \\
\hline \multicolumn{5}{|c|}{ Sample (adjusted): 186} \\
\hline \multicolumn{5}{|c|}{ Comprised observations: 86 afterward changes } \\
\hline Variable & Coefficient & Std. Error & t-Statistic & Prob. \\
\hline $\mathrm{PI}$ & 0.531287 & 0.046161 & 11.50944 & 0.0000 \\
\hline PNDT & -0.009946 & 0.089172 & -0.111535 & 0.9115 \\
\hline AREXP & 0.027515 & 0.244089 & 0.112724 & 0.9105 \\
\hline ASSEXP & 0.524589 & 0.180018 & 2.914097 & 0.0046 \\
\hline DEXP & 0.054935 & 0.108761 & 0.505098 & 0.6149 \\
\hline $\mathrm{C}$ & -0.374100 & 0.376078 & -0.994740 & 0.3229 \\
\hline R-squared & 0.975586 & \multicolumn{2}{|c|}{ Mean dependent var } & 8.848837 \\
\hline Adjusted R-squared & 0.974060 & \multicolumn{2}{|c|}{ S.D. dependent var } & 3.891219 \\
\hline S.E. of regression & 0.626715 & \multicolumn{2}{|c|}{ Akaike info criterion } & 1.970564 \\
\hline Sum squared resid & 31.42172 & \multicolumn{2}{|c|}{ Schwarz criterion } & 2.141798 \\
\hline Log likelihood & -78.73426 & \multicolumn{2}{|c|}{ Hannan-Quinn criter. } & 2.039478 \\
\hline F-statistic & 639.3606 & \multicolumn{2}{|c|}{ Durbin-Watson stat } & 0.708098 \\
\hline Prob(F-statistic) & 0.000000 & & & \\
\hline
\end{tabular}




\section{Project Culture}

The outcome of the investigation demonstrates that the projected model's forecast of method maturity is powerfully correlated to that of the forecast. The assessment result shows that almost 80 percent of the employee of the planning and development department agreed that project culture plays a vital and have an important role in the organizational project management performance. On normal of the employees achieve only $2 / 3$ of the project management performs that are measured to be elementary in handling dissimilar projects.

In this context the moderately inferior level of project management maturity practices could be because of the shared practices in the organization to extravagance them a task to be accomplished by the operational department and are not typically carefully managed in the project management. It appears there is considerate in the developing countries like Pakistan, specifically in KPK. For instance, although integration management, material administration, and configuration management are not well thought-out in project management.

\section{Organizational leadership}

The outcome of the analysis shows that the model is positively correlated to that of the forecast. The result shows that almost 86 percent of the employee of the planning and development agreed that organizational leadership plays a vital and important role in project management performance. On regular of the employees do only $2 / 3$ of the project management practices that are careful to be rudimentary in managing a different kind of projects.

This research finding also indicates that besides the important and vital role of organizational leadership in mature organizational project management, projects culture is neglected in management different projects.

\section{Organizational Project Management Maturity}

The outcome shows that project management maturity is greatly dependent on the project culture and organizational leadership. The 80 percent of the staff of planning and development agreed to the organizational project management performance is highly dependent on the project culture and organizational leadership.

\section{Discussions}

The discussion on the regression suggests that the project culture has a positive relationship with the organizational project management performance and the improvement in the management quality and the conventions used by the culture to motivate and direct the employees in the project has positive consequences for the organizational project management performance.

The organizational leadership has also strong saying to the organizational project management performance. Professional, detailed and strategically directed plans for the success of the projects are considered important for the success of the projects. The regression model validates the point that the organizational leadership in a project is positively related to the organizational project management performance.

The planning and development team and training are also considered important for measuring organizational project management performance. The results of the study suggest that the planning 
and development team and training have a director impact on the organizational project management performance.

Project initiative is also considered to be another important factor when investigating the organizational project management performance. If the project initiative is high in number, the organizational project management performance will be well high.

\section{Conclusion}

The result reveal that the deployment of project culture and organizational leadership has positive and significant impact on organizational project management performance as well as overall organizational performance. Results produced through analysis shows that the criteria have significant association with project management performance that ultimately prove over main assumption.

Our preliminary findings concluded that the project culture and organizational leadership play a vital role in the development of organizational project management practices. The findings highlight the exercise of the project management are less practiced than the facts and determination to the application of project management methods.

The findings also highlighted that the standard project practices are less performs than the knowledge of the project management approaches. One big reason is the inadequate usage of upto-date practices, tool, methods and standards in the organizations in KPK. Another reason can be the academic training in project management is not so enough. It comes to the hesitation when it comes to the practicing the existing formal and informal training programs.

The implication of the research helps in the policy formulation regarding strong leadership in the successful implementation of the project management practices within organization.

\section{Limitations and Further Research}

- The study was investigated in Khyber Pakhtunkhwa public universities and only Planning \& Development Staff.

- The restriction of schedule, budget, and resources have extra dependable and enlightening techniques, for instance, different kind of maturity assessment and investigation of organizations based on objects and Interviews.

- The analysis can also be extended to cover the private universities in KPK and then to overall Pakistan universities.

- It will be interesting to encounter more studies on these empirical foundations to disclose more accurately the mechanisms by which superior practices can be developed over time.

\section{References}

Abbas, S. Raza. S. (2011). Project Management Practices in e-Government Projects: A Case Study of Electronic Government Directorate (EGD) in Pakistan, 2(7).

Abbasi, G., \& Al-Mharmah, H. (2000). Project management practice by the public sector in a developing country. International Journal of Project Management, 18(2), 105-109.

https://doi.org/10.1016/S0263-7863(98)00074-X

Abbasi, S., \& Hollman, K. W. (2000). Turnover: The Real Bottom Line. Public Personnel Management, 29(3), 333-342. https://doi.org/10.1177/009102600002900303 
INTERNATIONAL JOURNAL OF ACADEMIC RESEARCH IN BUSINESS AND SOCIAL SCIENCES

Vol. 9, No. 3, March, 2019, E-ISSN: 222 2-6990 @ 2019 HRMARS

Arnaboldi, M., \& Lapsley, I. (2004). Modern Costing Innovations and Legitimation: A Health Care Study. Abacus, 40(1), 1-20. https://doi.org/10.1111/j.1467-6281.2004.00143.x

Backlund, F., Chronéer, D., \& Sundqvist, E. (2014). Project Management Maturity Models - A Critical Review. Procedia - Social and Behavioral Sciences, 119, 837-846.

https://doi.org/10.1016/j.sbspro.2014.03.094

Bergman, I., \& Gunnarson, S. (2014). Teaching Organizational Project Management at Postgraduate Level. Procedia - Social and Behavioral Sciences, 119, 446-455. https://doi.org/10.1016/j.sbspro.2014.03.050

Bredillet, C. N., Thomas, J., \& Musila, J. (2012). From the Editors. Project Management Journal, 43(4), 2-4. https://doi.org/10.1002/pmj.21286

Denison, D., Janovics, J., Young, J., Hee, J., \& Cho. (2006). Diagnosing organizational cultures: Validating a model and method.

Fleishman, E. A., \& Mumford, M. D. (1991). Evaluating Classifications Of Job Behavior: A Construct Validation Of The Ability Requirement Scales. Personnel Psychology, 44(3), 523-575. https://doi.org/10.1111/j.1744-6570.1991.tb02403.x

HUTSON, E. (1997). The Market for Corporate Control In Australia. Economic Papers: a Journal of Applied Economics and Policy, 16(2), 51-61. https://doi.org/10.1111/j.17593441.1997.tb00147.x

Istrate, L., \& Marian, L. (2012). Research on the Use of Project Management in Organizational Culture Change in Public Administration Institutions. Procedia Economics and Finance, 3, 617622. https://doi.org/10.1016/S2212-5671(12)00204-3

Kirkpatrick, S. A., \& Locke, E. A. (1991). Leadership: Do Traits Matter? The Executive, 5(2), 48-60. Kotter, J. P. (1990). A Force for Change: How Leadership Differs from Management.

Locke, E. A. (2005). Why emotional intelligence is an invalid concept. Journal of Organizational Behavior, 26(4), 425-431. https://doi.org/10.1002/job.318

Mathur, G., Jugdev, K., \& Shing Fung, T. (2007). Intangible project management assets as determinants of competitive advantage. Management Research News, 30(7), 460-475. https://doi.org/10.1108/01409170710759694

Milosevic, D., \& Patanakul, P. (2005). Standardized project management may increase development projects success. International Journal of Project Management, 23(3), 181-192.

https://doi.org/10.1016/j.ijproman.2004.11.002

Mukherjee, Debmalya, Lahiri, S., Mukherjee, Deepraj, \& Billing, T. K. (2012). Leading virtual teams: How do social, cognitive, and behavioral capabilities matter? Management Decision, 50(2), 273290. https://doi.org/10.1108/00251741211203560

Müller, R., \& Turner, J. R. (2007). Matching the project manager's leadership style to project type. International Journal of Project Management, 25(1), 21-32. https://doi.org/10.1016/j.ijproman.2006.04.003

Muriithi, N., \& Crawford, L. (2003). Approaches to project management in Africa: Implications for international development projects. International Journal of Project Management, 21(5), 309319. https://doi.org/10.1016/S0263-7863(02)00048-0 
Oliveira Moraes, R. de, \& Barbin Laurindo, F. J. (2013). Performance Evaluation of IT Projects - The Shenhar and Dvir Model. Journal of Technology Management \& Innovation, 8, 3-4. https://doi.org/10.4067/S0718-27242013000300002

Parchami Jalal, M., \& Matin Koosha, S. (2015). Identifying organizational variables affecting project management office characteristics and analyzing their correlations in the Iranian projectoriented organizations of the construction industry. International Journal of Project Management, 33(2), 458-466. https://doi.org/10.1016/j.ijproman.2014.06.010

Rodney Turner, J., Müller, R., \& Dulewicz, V. (2009). Comparing the leadership styles of functional and project managers. International Journal of Managing Projects in Business, 2(2), 198-216. https://doi.org/10.1108/17538370910949266

Stankosky, M., \& Anantatmula, V. S. (2010). Impact of cultural differences on knowledge management in global projects. VINE, 40(3/4), 239-253. https://doi.org/10.1108/03055721011071377

Stanleigh, M. (2008). Effecting successful change management initiatives. Industrial and Commercial Training, 40(1), 34-37. https://doi.org/10.1108/00197850810841620

Stuckenbruck, L. C., \& Zomorrodian, A. (1987). Project management: The promise for developing countries. International Journal of Project Management, 5(3), 167-175. https://doi.org/10.1016/0263-7863(87)90022-6

Wanna, J. (2007). Improving Implementation: Organizational Change and Project Management: ANU Press.

Yang, Y., Read, S. J., \& Miller, L. C. (2009). The Concept of Situations. Social and Personality Psychology Compass, 3(6), 1018-1037. https://doi.org/10.1111/j.1751-9004.2009.00236.x

Zuo, J., Zillante, G., Zhao, Z.-Y., \& Xia, B. (2014). Does project culture matter?: A comparative study of two major hospital projects. Facilities, 32(13/14), 801-824. https://doi.org/10.1108/F-022013-0014 